\title{
PERCEIVED BEHAVIORAL CONTROL DIABETES MELITUS TERKAIT LOCUS OF CONTROL PENDERITA DM
}

\author{
Perceived Behavioral Control Diabetes Mellitus related to Locus of Control DM Patients \\ Yusran Haskas, Indra Dewi, Fatimah \\ Sekolah Tinggi Ilmu Kesehatan Nani Hasanuddin Makassar \\ E-mail korespondensi : yusranhaskas@stikesnh.ac.id
}

\begin{abstract}
Controlling Diabetes Mellitus requires strong confidence and adherence so that people with Diabetes Mellitus can create these behaviors. The creation of a behavior cannot be separated from the role of the individual control center itself or in this case called the Locus of Control. The purpose of this study was to analyze the related of Locus of Control with patients Diabetes Mellitus to the Perceived Behavioral Control. This type of research is explanatory research using a cross-sectional design. The sampling technique was consecutive sampling with a large sample was determined using multivariate numerical analysis so that the sample size has 143 respondents. Hypothesis testing is carried out using the One Way Anova test. Statistical results show that the majority of respondents were more than to have an internal locus of control of $88.1 \%$. Statistical results show that locus of control has a significant effect on the perceived behavioral control of Diabetes Mellitus patients $(\rho=0.051)\left(\alpha=0.06 ; b=0.027 ; b^{2}=0.001\right)$. The results of this study concluded that locus of control had a significant effect on the perceived behavioral control of Diabetes Mellitus patients in diabetes mellitus control behavior.

Keywords: diabetes mellitus, locus of control, perceived behavioral control
\end{abstract}

\section{ABSTRAK}

Mengendalikan dan mengontrol penyakit Diabetes Melitus memerlukan keyakinan dan kepatuhan yang kuat agar penderita Diabetes Melitus dapat menciptakan perilaku tersebut. Terciptanya sebuah perilaku tersebut tidak lepas dari peran pusat kendali individu itu sendiri atau dalam hal ini disebut Locus of Control. Tujuan dari penelitian ini adalah menganalisis kaitan Locus of Control penderita Diabetes Melitus untuk melakukan pengendalian terhadap Perceived Behavioral Control yang dimiliki. Jenis penelitian explanatory research dengan menggunakan desain cross-sectional. Teknik pengambilan sampel consecutive sampling dengan besar sampel ditentukan menggunakan analitik multivariat numerik, sehingga besar sampel yang diperoleh sebanyak 143 responden. Pengujian hipotesis dilakukan dengan menggunakan uji One Way Anova. Hasil statistik menunjukkan bahwa sebagian besar responden lebih cenderung memiliki internal locus of control yakni $88,1 \%$. Hasil menunjukkan bahwa locus of control berpengaruh signifikan terhadap perceived behavioral control penderita DM $(\rho=0,051)\left(\alpha=0,06 ; b=0,027 ; b^{2}=0,001\right)$. Berdasarkan hasil penelitian dapat disimpulkan bahwa locus of control berpengaruh signifikan terhadap perceived behavioral control penderita DM dalam perilaku pengendalian diabetes melitus.

Kata kunci : diabetes melitus, locus of control, perceived behavioral control

\section{PENDAHULUAN}

Whiting (2011) mengemukakan bahwa Diabetes Melitus (DM) merupakan penyakit kronis yang paling umum berada di hampir semua negara dan terus mengalami peningkatan dalam jumlah yang signifikan. Secara global diperkirakan ada sekitar 364 juta orang yang menderita DM dan jumlah tersebut terus mengalami peningkatan setiap tahunnya (WHO, 2015). Mengingat prevalensi DM yang semakin meningkat di setiap tahunnya, maka pengendalian DM sangat penting untuk diterapkan. Individu yang kemudian akan melakukan pengendalian memiliki beberapa faktor pendukung dan penghambat sehingga barulah dapat terbentuk suatu perilaku pengendalian.

Locus of control (LoC) digambarkan sebagai keyakinan individu terhadap kemampuan dalam mengontrol kehidupannya yang merupakan ciri kepribadian dari individu (Rotter, 1966). Karakteristik kepribadian kemudian diuraikan oleh orang-orang dengan anggapan bahwa kendali kehidupan berasal dari dalam diri mereka sendiri dan dari faktor diluar diri mereka (Gibson et al., 2014). Sehingga LoC berdasarkan karakteristik kepribadian individu terbagi atas internal dan eksternal yang kemudian menimbulkan harapan berupa hasil dari perilaku (Rotter, 1966).

Menurut Wallston (2001), locus of control dapat berada pada internal maupun ekstrenal individu dikarenakan mengacu pada tempat berasalnya kontrol. Berdasarkan hal tersebut LoC dapat dikatakan sebagai cara menggambarkan individu memandang hubungan antara perbuatan yang dilakukannya (action) dengan akibat maupun hasilnya (outcome) (Larsen \& Buss, 2005). LoC atau pusat 
kendali memiliki peran penting dalam kehidupan seseorang, seperti terkait kesehatan, kebahagiaan, kepuasan kerja dan kehidupan secara keseluruhan (O’Driscoll \& Jeggo, 2006).

Seseorang dengan LoC internal percaya bahwa hasil dan perilaku mereka disebabkan oleh faktor dari dalam dirinya, sedangkan seseorang dengan LoC eksternal percaya bahwa hasil dan perilakunya disebabkan oleh faktor dari luar dirinya (Rotter, 1966). Seperti penelitian yang dilakukan oleh Seeman \& Evans (1962), menunjukkan bahwa individu yang memiliki internal LoC merupakan individu yang aktif mencari informasi terkait dengan kesehatannya, sehingga individu tersebut lebih memahami kondisi mereka dan lebih bertanya kepada dokter, perawat mengenai kondisi kesehatannya jika dibandingkan dengan individu yang memiliki LoC eksternal. Hal tersebut sejalan dengan pendapat K. A. Wallston (1981), yang menyatakan bahwa individu yang memiliki LoC internal cenderung terlibat dalam perilaku sehat, sebaliknya individu yang memiliki LoC eksternal cenderung terlibat dalam perilaku yang dapat merusak kesehatan.

$$
\text { Bonichini et al., (2009) }
$$
mengemukakan bahwa LoC dapat memengaruhi perilaku individu yang berhubungan dengan kesehatan, termasuk perilaku yang berisiko dan kepatuhan terhadap anjuran perawatan kesehatan. Sehingga menurut K. Wallston (2001) dan Krampen (1991), LoC merupakan salah satu tipe dari control belief dengan gagasan internal dan eksternal yang serupa. Berdasarkan hal tersebut maka dapat dikatakan bahwa LoC berperan ketika individu memprediksikan berbagai faktor yang dapat mendukung terciptanya perilaku, baik itu faktor internal maupun eksternal. Dimana kemudian faktor pendukung yang ada akan membentuk keyakinan individu untuk berperilaku (control belief). Jadi, LoC bukanlah sebuah keyakinan, melainkan sumber (source) pembentuk keyakinan.

Terbentuknya keyakinan dapat menghasilkan suatu bentuk perilaku pengendalian, salah satunya adalah pengendalian DM. DM sendiri merupakan penyakit yang belum dapat disembuhkan, sehingga yang dapat dilakukan adalah dengan mengontrol dan mengendalikan tindakan yang berhubungan dengan penyakit tersebut agar penderita dapat mempertahankan kualitas hidupnya. Hal tersebut bisa dilihat dengan bagaimana penderita menggambarkan perasaan atas kemampuan dirinya dalam melakukan suatu perilaku, atau bisa disebut dengan Perceived Behavioral Control (PBC).

Menurut Ismail \& Zain (2008), PBC merupakan sebuah persepsi individu mengenai kontrol yang dimiliki berhubungan dengan tingkah laku tertentu. Dimana hal terkait dengan keyakinan tentang ada atau tidaknya faktor yang memfasilitasi dan menghalangi individu untuk melakukan suatu perilaku. Ini ditentukan oleh bagaimana pengalaman dan juga perkiraan individu mengenai sulit atau mudahnya dalam melakukan suatu perilaku.

PBC akan merepresentasikan kepercayaan seseorang tentang mudah atau sulitnya menampilkan suatu perilaku. Seperti yang dikemukakan oleh Ajzen \& Zinger (1991) menjelaskan perilaku seseorang tidak hanya dikendalikan oleh dirinya sendiri, akan tetapi juga membutuhkan kontrol berupa ketersediaan sumber daya, kesempatan dan keterampilan tertentu. Dimana ketika individu merasa percaya dirinya kekurangan sumber atau tidak memiliki kesempatan untuk menampilkan suatu perilaku, maka individu tersebut tidak memiliki intensi yang kuat untuk menunjukkan perilaku tersebut (Engel et al., 1995).

Mengontrol dan mengendalikan tindakan yang berhubungan dengan penyakit DM dapat mempertahankan kualitas hidup penderita. Sehingga kondisi penderita dapat disimpulkan bergantung pada dirinya sendiri, terutama dari segi kepatuhan dan disiplin untuk melakukan pengendalian penyakit dengan benar. Tujuan dan penelitian ini adalah untuk melihat peran LoC dalam memprediksikan faktor yang dapat menciptakan suatu perilaku dengan mempertimbangkan dapat atau tidaknya suatu perilaku tercipta berdasarkan PBC yang dimiliki oleh individu tersebut.

\section{METODE PENELITIAN \\ Desain, Tempat dan Waktu}

Jenis penelitian yang digunakan explanatory research yaitu penelitian yang bertujuan untuk menganalisis hubungan antara satu variabel dengan variabel yang 
lainnya atau proses suatu variabel memengaruhi variabel lainnya menggunakan desain potong lintang (crosssectiona). Penelitian ini dilaksanakan di delapan lokasi, terdiri dari tiga rumah sakit yang ada di Kota Makassar dan lima puskesmas yaitu RS Tk. II Pelamonia, RS Islam Faisal, RS Kota Makassar, Puskesmas Antang, Puskesmas Antara, Puskesmas Batua, Puskesmas Sudiang Raya dan Puskesmas Tamalanrea Jaya. Pemilihan lokasi tersebut dilakukan dengan cara random lottery. Waktu pelaksanaan penelitian ini dilakukan mulai bulan Juni sampai Agustus tahun 2015.

\section{Jumlah dan Cara Pengambilan Subjek}

Besar sampel pada penelitian ini diperoleh sebanyak 143 responden dengan sampelnya merupakan seluruh penderita DM yang berobat ke lokasi penelitian. Teknik pengambilan sampel dalam penelitian ini adalah consecutive sampling yang merupakan pemilihan sampel dengan cara berurutan yang ditetapkan berdasarkan kriteria penelitian sampai mendapatkan besar sampel yang diinginkan atau sampai masa penelitian berakhir (Currier, 1984). Variabel dalam penelitan ini adalah LoC yang terdiri atas internal LoC dan eksternal LoC, sedangkan variabel dependen pada penelitian ini adalah PBC.

\section{Jenis dan Cara Pengelolaan Data}

Alat ukur yang digunakan berupa kuesioner berbentuk check list. Hipotesis diuji menggunakan uji statistik dengan nilai $\alpha=0.06$ dengan maksud bahwa peluang terjadinya kesalahan dalam pengukuran sebanyak $6 \%$ dari total pengukuran. Uji yang digunakan untuk menguji pengaruh LoC terhadap PBC yaitu menggunakan uji One Way Anova.

\section{HASIL}

Berdasarkan penelitian yang dilakukan hasil analisa univariat 143 responden menunjukkan bahwa pada tabel 1 menunjukkan sebagian besar responden telah menderita DM selama $>5$ tahun yakni sebesar $48.3 \%$ dan tidak mengalami komplikasi DM sebesar $55.9 \%$ serta sebagian besar responden lebih cenderung memiliki internal LoC yakni $88.1 \%$. Tabel 2 . menunjukkan berdasarkan lama menderita $\mathrm{DM}$, persentase responden yang menderita $\mathrm{DM}>5$ tahun lebih tinggi pada internal LoC $(91.3 \%)$ dibandingkan dengan eksternal LoC $(8.7 \%)$. Sehingga dapat disimpulkan bahwa semakin lama seseorang menderita DM maka akan semakin cenderung pada internal LoC. Sedangkan berdasarkan ada tidaknya komplikasi, persentase responden yang belum mengalami komplikasi lebih tinggi pada internal LoC (90\%) dibandingkan dengan eksternal LoC $(10 \%)$. Tabel 3. menunjukkan bahwa persepsi responden bisa tidaknya mengontrol perilaku (PBC), dimana terdapat $100 \%$ responden dengan eksternal LoC memiliki persepsi yang baik dan $99.2 \%$ responden dengan internal LoC juga memiliki persepsi yang baik. Sehingga dapat disimpulkan berdasarkan hasil analisa bivariat bahwa responden dapat mengontrol perilakunya, dikarenakan semakin besar nilai internal LoC maka semakin baik pula persepsi penderita akan kontrol pengendalian DM. Dimana hasil uji statistik ini menunjukkan nilai $\rho=0.051$ yang berarti bahwa LoC berpengaruh signifikan terhadap PBC penderita DM, dengan nilai beta positif menunjukkan bahwa semakin internal LoC penderita terkait DM maka semakin baik persepsinya untuk mampu melakukan pengendalian DM.

\section{PEMBAHASAN}

Penelitian ini mengkaji Perceived behavioral control (PBC) yang merupakan persepsi penderita mengenai kontrol perilakunya terkait pengendalian DM. Tolak ukurnya adalah kekuatan persepsi penderita bahwa dapat tidaknya mengontrol perilaku pengendalian DM. Sebagian besar penderita internal dan eksternal LoC mempersepsikan kemampuannya mengontrol perilaku terkait pengendalian DM.

Penderita dengan internal LoC mempersepsikan bahwa untuk mengendalikan DM berada di bawah kendalinya, bergantung pada usaha sendiri. Akan tetapi, persepsi yang sama juga terjadi pada penderita dengan eksternal LoC yang mempersepsikan bahwa sumbangsi dari pihak luar (dokter, keluarga dan teman) juga mampu meningkatkan compliance penderita terkait pengendalian DM. Hasil penelitian ini ditemukan bahwa LoC turut mengambil peran terhadap PBC penderita terkait pengendalian DM.

Perceived behavioral control penderita terkait dengan pengendalian DM ditentukan pula berdasarkan pada pengalaman masa lalu penderita dan 
persepsinya mengenai seberapa sulit atau mudahnya untuk melakukan pengendalian DM. Pengalaman tersebut dapat dipengaruhi oleh informasi yang diperoleh dari orang lain, selain itu juga dipengaruhi oleh faktor pendidikan dan usia, keterbatasan dari segi pengetahuan serta budaya juga dipandang sebagai alasan yang menyebabkan persepsi kontrol perilaku penderita berbeda-beda terkait pengendalian DM. Perceived behavioral control mewakili keyakinan penderita tentang seberapa mudah individu menampilkan perilaku pengendalian DM.

Saat penderita yakin bahwa dirinya kekurangan sumber atau tidak memiliki kesempatan untuk menampilkan perilaku pengendalian DM, maka ia akan mempersepsikan bahwa dirinya memiliki kontrol yang rendah terkait perilaku DM. Penderita dengan internal LoC akan memiliki persepsi bahwa ia dapat kembali sehat setelah mengalami sakit dengan berusaha mengendalikan tingkah lakunya. Sedangkan penderita dengan eksternal LoC memiliki persepsi bahwa powerful others, faktor nasib atau hanya kebetulan (chance) yang menentukan kesehatannya terkait pengendalian DM.

Menurut Ajzen (2005), penderita internal dan eksternal LoC dalam mengendalikan perceived behavioral diabetic control tentunya memperhatikan dua hal yaitu control belief dan perceived power. Control belief merepresentasikan kemampuan penderita untuk mengontrol perilakunya terkait pengendalian DM terhadap faktor dari luar penderita yang menghambat atau mendukung untuk menampilkan perilaku yang berasal dari luar. Perceived power mengutamakan kemampuan penderita untuk mengontrol perilakunya terkait pengendalian DM terhadap faktor dari dalam penderita yang menghambat atau mendukung penderita untuk menampilkan perilaku yang berasal dari dalam diri penderita.

Kombinasi tersebut akan membentuk perceived behavioral control penderita yang baik terkait pengendalian DM. Implikasi dari penelitian ini dapat ditemukan bahwa kontribusi LoC memberi pengaruh terhadap PBC terkait pengendalian DM secara langsung. Sumber kontrol merupakan kekuatan utama bagi penderita baik yang cenderung internal atau eksternal maupun keduanya.

\section{KESIMPULAN}

Berdasarkan hasil penelitian yang dilakukan dapat disimpulkan bahwa LoC berpengaruh signifikan terhadap PBC dalam perilaku pengendalian DM. Persepsi penderita akan pengendalian DM dipicu dari berbagai sumber kendali (LoC) baik internal maupun eksternal.

\section{SARAN}

Penting untuk meningkatkan keterlibatan pasien dalam mengisi locus of control dengan mencari informasi dan memperluas jejaring sosial sehingga banyak sumber yang dapat meningkatkan persepsi dan membentuk perilaku kontrol diabetes melitus.

\section{DAFTAR PUSTAKA}

Ajzen, I. (2005). Laws of human behavior: symmetry, compatibility, and attitude behavior correspondence. (A. Beauducel, B. Biehl, M. Bosniak, W. Conrad, G. Schonberger, \& D. Wagener, Eds.). Germany: Shaker Verlag.

Ajzen, I., \& Zinger, D. (1991). The theory of planned behavior. Organizational Behavior and Human Decision Processes, 50(2), 179-211. https://doi.org/10.1016/07495978(91)90020-T

Bonichini, S., Axia, G., \& Bornstein, M. H. (2009). Validation of the parent health locus of control scales in an Italian sample. Italian Journal of Pediatrics, 35(13), 1-5. https://doi.org/10.1186/1824-7288-3513

Currier, D. P. (1984). Elements of Research in Physical Therapy. Williams \& Wilkins.

Engel, J. F., Blackwell, R. D., \& Miniard, P. W. (1995). Consumer Behavior. International Edition.

Gibson, J. L., Ivancevich, J. M., James H. Donnelly, J., \& Konopaske, R. (2014). Organizations - Behavior, Structure, Processes, Fourteenth Edition. McGraw-Hill. https://doi.org/10.1007/s13398-0140173-7.2

Ismail, V. Y., \& Zain, E. (2008). Peranan Sikap, Norma Subjektif dan Perceived Behavioral Control Terhadap Intensi Pelajar SLTA untuk Memilih Fakultas Ekonomi. Jurnal Ekonomi Dan Bisnis, 5(3), 237-257. 
Krampen, G. (1991). Political participation in an action-theory model of personality: Theory and empirical evidence. Political Psychology. https://doi.org/10.2307/3791343

Larsen, R. J., \& Buss, D. M. (2005). Personality Psychology. Domains of knowledge about human nature. Psychology.

Madden, T. J., Ellen, P. S., \& Ajzen, I. (University of M.-A. (1992). A Comparison of the Theory of Planned Behavior and the Theory of Reasoned Action. Personality and Social Psychology Bulletin, 18(1), 3-9. https://doi.org/10.1177/014616729218 1001

O'Driscoll, M., \& Jeggo, P. A. (2006). The role of double-strand break repair Insights from human genetics. Nature Reviews Genetics, 7(1), 45-54. https://doi.org/10.1038/nrg1746

Rotter, J. B. (1966). Generalized expectancies for internal versus external control of reinforcement. Psychological Monographs, 80(1), 128. https://doi.org/10.1037/h0092976

Seeman, M., \& Evans, J. W. (1962).
Alienation and Learning in a Hospital Setting. American Sociological Review, 27(6), 772. https://doi.org/10.2307/2090405

Wallston, K. (2001). Conceptualization and Operationalization of Perceive d Control. Handbook of Health Psychology. Retrieved from http://scholar.google.com/scholar?hl= en\&btnG=Search\&q=intitle:Conceptua lization+and+Operationalization+of+P erceive $+d+$ Control\#0

Wallston, K. A. (1981). Health locus of control scales. Research with the Locus of Control

Whiting, D. R. dkk. (2011). International diabetes federation, diabetes atlas: global estimates of the prevalence of diabetes for 2011 and 2030. Diabetes Research and Clinical Practice, 94(3), 94:311-321.

https://doi.org/http://dx.doi.org/10.101 6/j.diabres.2011.10.029

WHO. (2015). Obesity and overweight. Fact sheet

311. https://doi.org/10.1080/108107309032 79694 


\section{LAMPIRAN}

Tabel 1. Distribusi Frekuensi Karakteristik Responden

\begin{tabular}{lcccccc}
\hline \multirow{2}{*}{ Karakteristik Responden } & \multicolumn{2}{c}{ RS } & \multicolumn{2}{c}{ Puskesmas } & \multicolumn{2}{c}{ Total } \\
\cline { 2 - 7 } & $\mathbf{n}$ & $\%$ & $\mathbf{n}$ & $\%$ & $\mathbf{n}$ & $\%$ \\
\hline Lama menderita DM & & & & & & \\
\hline <1 tahun & 12 & 14.8 & 5 & 8.1 & 17 & 11.9 \\
1-5 tahun & 33 & 40.7 & 24 & 38.7 & 57 & 33.9 \\
$\quad$ 5 tahun & 36 & 44.4 & 33 & 53.2 & 69 & 48.3 \\
\hline Komplikasi & & & & & & \\
\hline Tidak ada & 44 & 54.3 & 36 & 58.1 & 80 & 55.9 \\
$\quad$ Ada & 37 & 45.7 & 26 & 41.9 & 63 & 44.1 \\
\hline Locus of Control & & & & & & \\
\hline$\quad$ Internal & 72 & 88.9 & 54 & 87.1 & 126 & 88.1 \\
$\quad$ Eksternal & 9 & 11.1 & 8 & 12.9 & 17 & 11.9 \\
\hline
\end{tabular}

Tabel 2. Dimensi LoC berdasarkan lama menderita DM dan komplikasi

\begin{tabular}{ccccccc}
\hline $\begin{array}{c}\text { Karakteristik } \\
\text { Responden }\end{array}$ & \multicolumn{2}{c}{ Internal LoC } & \multicolumn{2}{c}{ External LoC } & \multicolumn{2}{c}{ Total } \\
\cline { 2 - 7 } & $\mathbf{n}$ & $\%$ & $\mathbf{n}$ & $\%$ & $\mathbf{n}$ & $\%$ \\
\hline Lama menderita DM & & & & & & \\
\hline$<1$ tahun & 13 & 76.5 & 4 & 23.5 & 17 & 100 \\
\hline $1-5$ tahun & 50 & 87.7 & 7 & 12.3 & 57 & 100 \\
\hline$>5$ tahun & 63 & 91.3 & 6 & 8.7 & 69 & 100 \\
\hline Komplikasi & & & & & & \\
\hline Tidak ada & 72 & 90 & 8 & 10 & 80 & 100 \\
\hline Ada & 54 & 85.7 & 9 & 14.3 & 63 & 100 \\
\hline
\end{tabular}

Tabel 3. Pengaruh LoC terhadap PBC pada penderita DM

\begin{tabular}{ccccccccc}
\hline \multirow{2}{*}{$\begin{array}{c}\text { Locus of } \\
\text { Control }\end{array}$} & \multicolumn{2}{c}{ Perceived Behavioral Control } & \multicolumn{2}{c}{ Total } & b & p \\
\cline { 2 - 7 } & $\mathbf{n}$ & $\%$ & $\mathbf{n}$ & $\%$ & $\mathbf{n}$ & $\%$ & & \\
\hline Eksternal & 0 & 0.0 & 17 & 100.0 & 17 & 100.0 & & \\
\hline Internal & 9 & 7.1 & 117 & 92.9 & 126 & 100.0 & 0.027 & 0.051 \\
\hline Total & 9 & 6.3 & 134 & 92.7 & 143 & 100.0 & & \\
\hline
\end{tabular}

